\title{
ESSE: Learning Disability Classification System for Autism and Dyslexia
}

\author{
Nor'ain Mohd Yusoff ${ }^{1,2}$, Muhammad Hafiz Abdul Wahab ${ }^{2}$, \\ Mohamad Azrulnisyam Aziz ${ }^{2}$, and Fauzul Jalil Asha' ari ${ }^{2}$ \\ ${ }^{1}$ Faculty of Computer Science and Information Technology, University of Malaya, \\ Kuala Lumpur, Malaysia \\ norain.yusoffammu.edu.my \\ ${ }^{2}$ Faculty of Information Science and Technology, Multimedia University, \\ Melaka, Malaysia \\ seefueq@yahoo.com, motorbreth_03@yahoo.co.uk
}

\begin{abstract}
This paper presents an Expert System for Special Education (ESSE) based on scenario in Malaysia. This system is developed through the process of knowledge-gaining which is gathered from various expertise in chosen domain. Realizing the limitation of traditional classification system that teachers adopted, we developed ESSE to automate a centralized decision making system. ESSE is also able to provide consistent answers for repetitive decisions, processes and tasks. Besides, teachers using this system hold and maintain significant level of information pertaining both learning disabilities, thus reduce amount of human errors. ESSE knowledge-based resulted from the knowledge engineering called Qualifiers and Choice. Both are gathered from the analysis of symptoms that are experienced by Autism and Dyslexia patients. Every type of disability is divided to several categories and subcategory to facilitate question's arrangement. This paper presents a review of Expert System for Special Education (ESSE), problems arises and the knowledge-based classification systems.
\end{abstract}

Keywords: Qualifiers, Choice, Autism, Dyslexia, Knowledge Engineering.

\section{Introduction}

Nowadays, expert system application is the field that has a high demand in HumanComputer Interaction. There are a lot of demands in developing the expert system as an alternative of the human expertise especially in the domain of special education system.

In special education field, the new teachers need to know what type of disability that each of their students have, and they need to categorize the students into a suitable curriculum activity based on the students disability. Therefore, the result from this classification system can be a guideline and knowledge interpretation to their disabilities. Expert System for Special Education (ESSE) that we proposed is developed by using Incremental Expert System Prototyping Model, and adopting the Qualifiers and Choices for Autism and Dyslexia. The strength of this model is that users are 
allowed to recognize changes that are needed in future enhancement based on information and knowledge added by expertise. This paper presents a review of Expert System for Special Education (ESSE), problems arises and the knowledge-based classification systems.

\subsection{Background}

Malaysian Education Ministry provides education services to students that need special education in visual problem, hearing problem, learning problem, and student rehabilitation. Learning problem services under the Malaysian Education Ministry responsible can be categorized into Syndrome Down, Mild Autism, Attention Deficit Hyperactive Disorder (ADHD), Cerebral Palsy, and Specific Learning Problem (example : Dyslexia and Autism) [1].

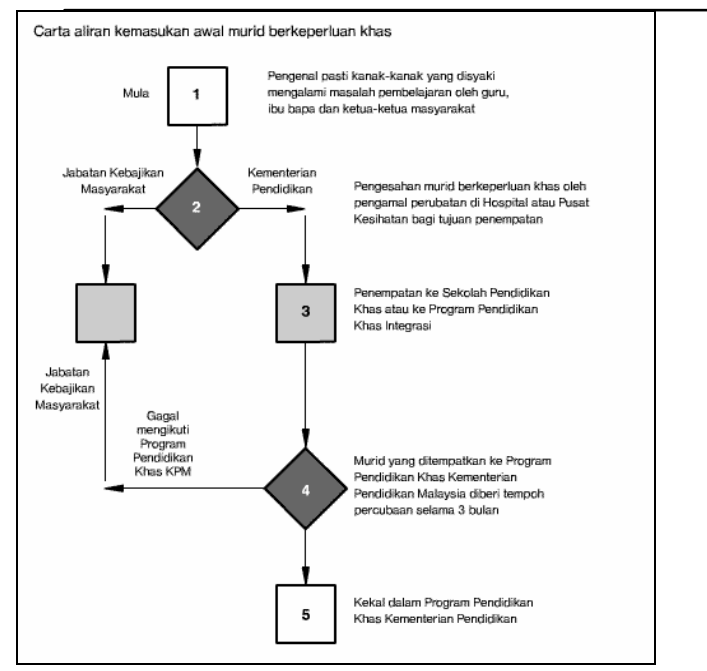

Fig. 1. The entry level process in special education

Remark

Process 1: The flow starts when the student is suspected to have learning problem by teachers, parents, or society leaders. Process 2: The student needs a disability approve letter from the doctors. Process 3: The student then is placed at Special Education School or enters the Special Education Integration Program. Process 4: Students who follow the Special Education Program will be tested in three months whether he will continued the program or not. Process 5: Students need to stay in special education program.

Our ESSE covered two out of five learning problem disabilities i.e. Autism and Dyslexia. Dyslexia and Autism is chosen among other type of learning problem because both of have higher number of children registered under the Malaysian Education Ministry. Syndrome Down was not chosen for this system because they can be categorized by recognition of faces and features. 


\subsection{Related Work}

Research in the screening and diagnosis of learning disabilities in Autism and Dyslexia is growing. Research by [4] concluded that DSM-III-R (American Psychiatric Association, 1994) and DSM-IV (American Psychiatric Association, 1994), together with ICD-10 (World Health Organization, 1993), had achieved agreed standardized measures in Autism. The first of these was the autism diagnostic interview, developed with [3]. The Autism Diagnostic Observation Schedule (ADOS) [5] was developed to determine social and communicative interaction what sorts of spontaneous interactions were initiated by the child and what kind of responses were made to the overtures of the investigator. [6] described two United Kingdom (UK) screening tests for dyslexia: the Dyslexia Early Screening Test (DEST) and the Cognitive Profiling System (COPS 1). Both normed and designed to be administered by teachers to children four years and older. There is a study to compare visual perception between both people in dyslexia and autistic spectrum disorders. [8] conduct a comparison of form and motion coherence processing in Autistic and Dyslexia. All of the above systems employ clinical interview and observation by experienced psychologists to screen and diagnose Autism and Dyslexia. None was done to classify both groups if they were mixed in the classroom. The screening process is relatively difficult when involve new teachers who do not have enough experiences and skills.

\section{Problem Statement}

Special Education Department does not have a system to help new teachers who lack of experience and information to identify the learning problems among students. Teachers were given short briefings or a motivations before they started to teach special education students. Therefore, problems will appear when the teachers' especially new teachers who did not have any experience or expertise to categorize type of disability and failed to understand the learning problem symptoms and to decide which curriculums activities are suitable for their students. Hence, curriculums activities that have been outlined by Malaysian Educational Ministry cannot be affectively applied to the students.

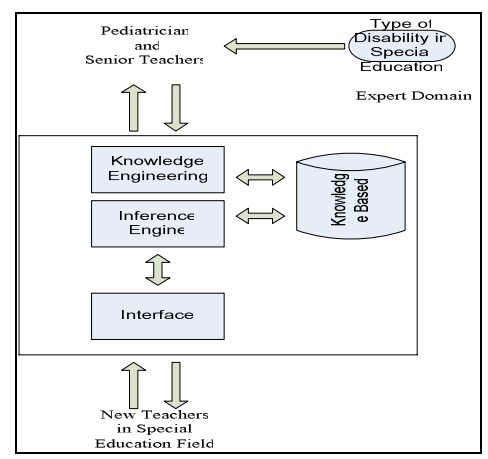

Fig. 2. The Scenario of Special Education System 
The objectives of ESSE as follows:

Build an expert system for special education i.e. Autism and Dyslexia

1 To categorize type of disability for special education students which is under Malaysian Educational Ministry

2 To find out related symptoms based on Qualifiers triggered in the Expert System

3 To associate Autism and Dyslexia students with appropriate special education according to their needs.

The result from the expert system will help new teachers in special education field categorized their students according to their disability. Thus, the teachers can decide which type of learning method is suitable for the students.

\section{Methodology}

ESSE that we proposed is developed by using Incremental Expert System Prototyping Model. The strength of his model is that users are allowed to recognize changes that are needed in future enhancement based on information and knowledge added by expertise.

Knowledge based is a combination of facts and knowledge. The function of knowledge based is to connect the facts and knowledge. Facts consist of qualifier and choice. While knowledge is consist of rules. Rules is generated from combination of qualifier and choice through the IF and THEN statement. Please refer to Table 1.

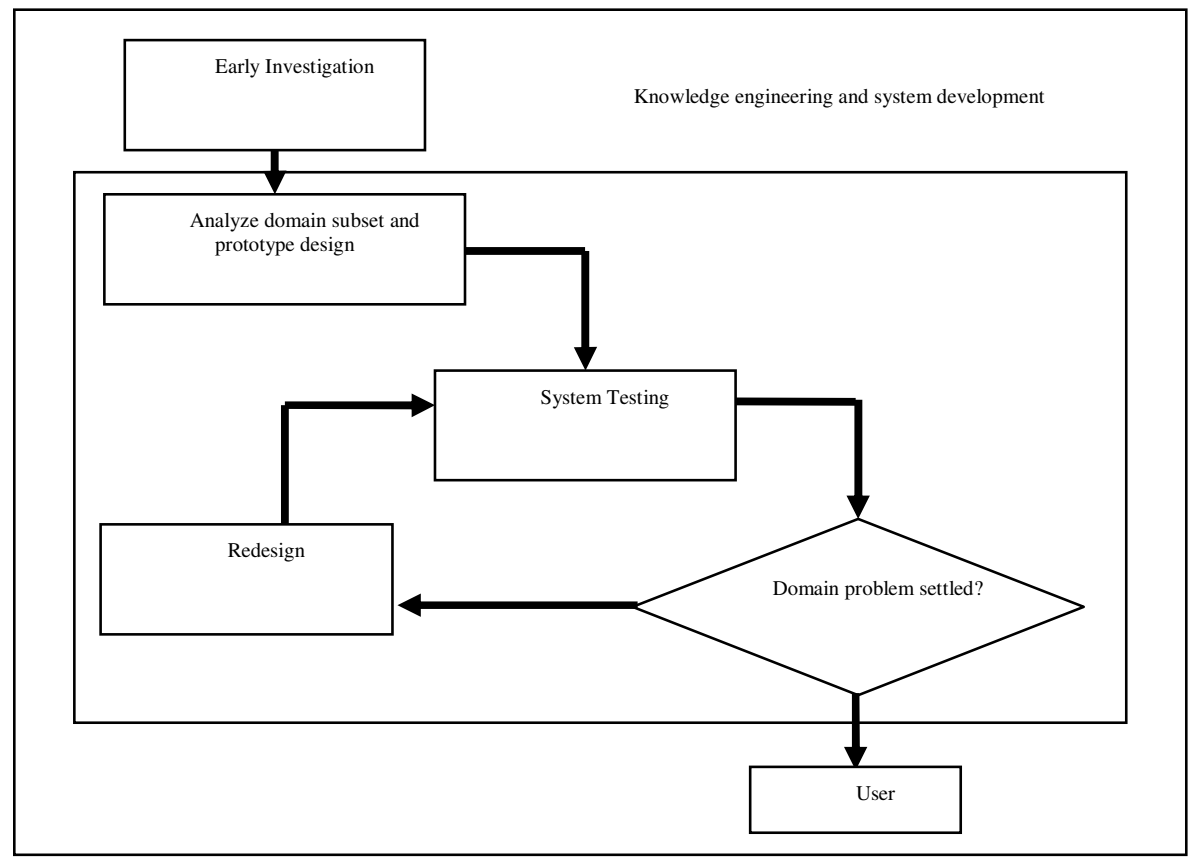

Fig. 3. Incremental Expert System Prototyping Methodology (Adapted from Darlington, 2000) 
Table 1. A Part of Qualifiers and Choice for Autism and Dyslexia

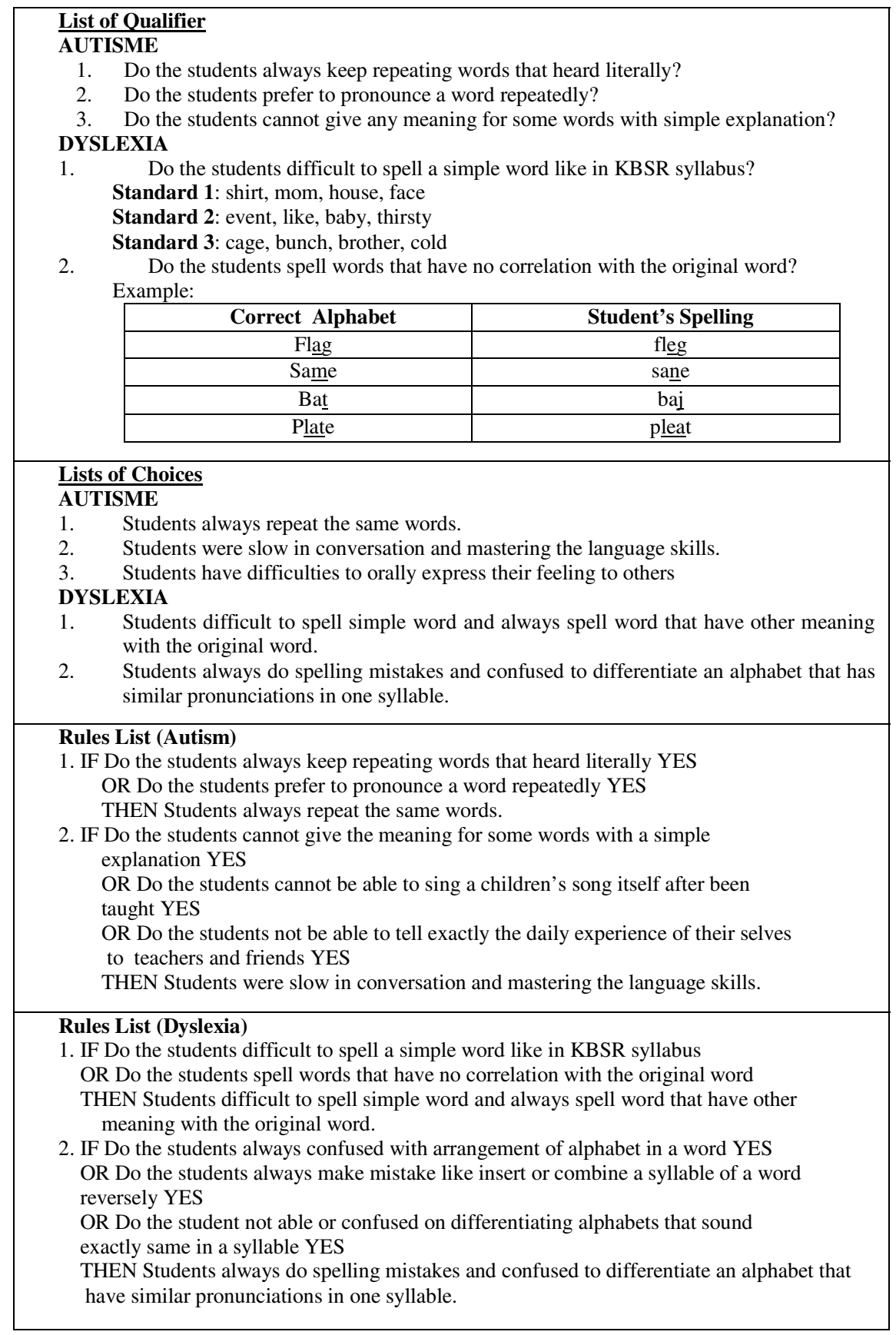




\section{ESSE System}

ESSE System supports the clinical diagnostic features in learning disabilities. Screening activities are crucial to early diagnosis. The purpose of screening is to identify children appropriately for autism and dyslexia as soon as possible so that they can be rapidly referred for suitable learning modules and interventions [7]. As such, ESSE further to assist to automate the decision-making system, and classify both learning disabilities to different learning modules. Fig. 4 shows the display of ESSE interfaces.

A Cognitive Map [see Fig. 5] is developed to summarize the overall movement and progress of the system nodes. We implement the system using Macromedia MX, ASP, and MYSQL.

Table 2. Schedule of Functionality and Unit Testing

\begin{tabular}{|c|c|c|}
\hline Criteria Tested & Expected Output & Result Output \\
\hline \multicolumn{3}{|l|}{$\begin{array}{c}\text { Autism } \\
\text { Information } \\
\text { Module }\end{array}$} \\
\hline $\begin{array}{l}\text { - Able to display } \\
\text { Autism Information's } \\
\text { interface }\end{array}$ & $\begin{array}{l}\text { Interface of Autism's disabilities will } \\
\text { be displayed when user clicks "Autism?" } \\
\text { menu in the "Main Menu". }\end{array}$ & Successful \\
\hline $\begin{array}{l}\text { - Navigate to next } \\
\text { page }\end{array}$ & $\begin{array}{l}\text { Interface of Autism information can be } \\
\text { linked to main menu when user clicks } \\
\text { "Main Menu". }\end{array}$ & Successful \\
\hline \multicolumn{3}{|l|}{$\begin{array}{l}\text { Dyslexia } \\
\text { Information } \\
\text { Module }\end{array}$} \\
\hline $\begin{array}{l}\text { - Able to display } \\
\text { Dyslexia } \\
\text { Information's } \\
\text { interface }\end{array}$ & $\begin{array}{l}\text { Interface of Dyslexia's information } \\
\text { disability will be displayed when user } \\
\text { clicks "Dyslexia?" menu in the "Main } \\
\text { Menu". }\end{array}$ & Successful \\
\hline $\begin{array}{l}\text { - Navigate to next } \\
\text { page }\end{array}$ & $\begin{array}{l}\text { Interface of Autism information can be } \\
\text { linked to main menu when user clicks } \\
\text { "Main Menu". }\end{array}$ & Successful \\
\hline \multicolumn{3}{|l|}{$\begin{array}{l}\text { Question } \\
\text { Module }\end{array}$} \\
\hline $\begin{array}{l}\text {-Able to display } \\
\text { question }\end{array}$ & $\begin{array}{l}\text { Interface of Question appear when } \\
\text { user clicks "Expert System" menu in the } \\
\text { Main Menu. }\end{array}$ & Successful \\
\hline $\begin{array}{l}\text { - Able to go to } \\
\text { next page }\end{array}$ & $\begin{array}{l}\text { Interface of the } 1^{\text {st }} \text { question's page can } \\
\text { be linked to next question by clicking on } \\
\text { "Next" button. }\end{array}$ & Successful \\
\hline $\begin{array}{l}\text { - Able to go to } \\
\text { the next page }\end{array}$ & $\begin{array}{l}\text { Interface of result can be linked to } \\
\text { "Main Menu" when user clicks to the } \\
\text { "Main Menu" button. }\end{array}$ & Successful \\
\hline \multicolumn{3}{|l|}{ Result Module } \\
\hline $\begin{array}{l}\text { - Able to display } \\
\text { result }\end{array}$ & $\begin{array}{l}\text { Interface of displaying student which } \\
\text { belongs to either group of Autism or } \\
\text { Dyslexia. }\end{array}$ & Successful \\
\hline $\begin{array}{l}\text { - Able to go to } \\
\text { the next page }\end{array}$ & $\begin{array}{l}\text { Interface of result can be linked to the } \\
\text { "Main Menu" if user clicks "Main Menu" } \\
\text { button. }\end{array}$ & Successful \\
\hline
\end{tabular}



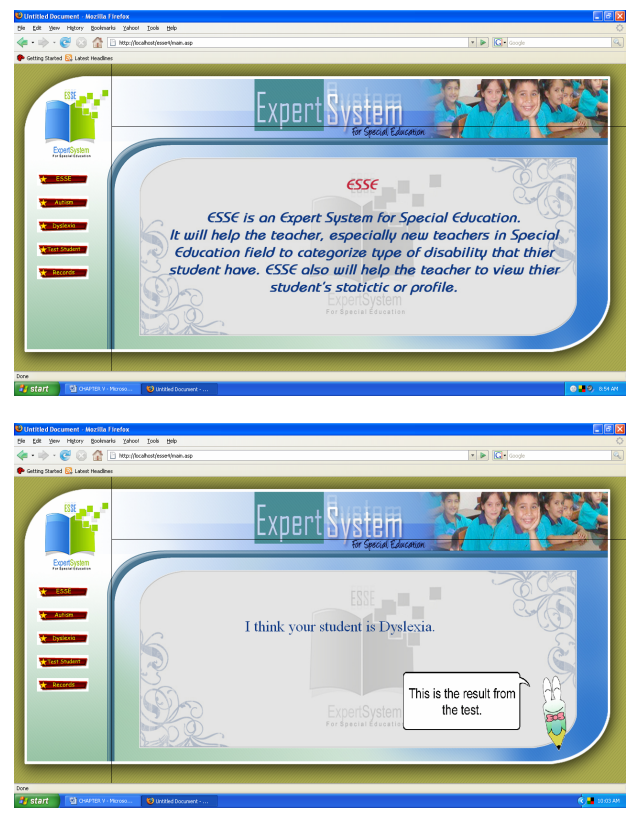

Fig. 4. Main Interface and Result Display Interface

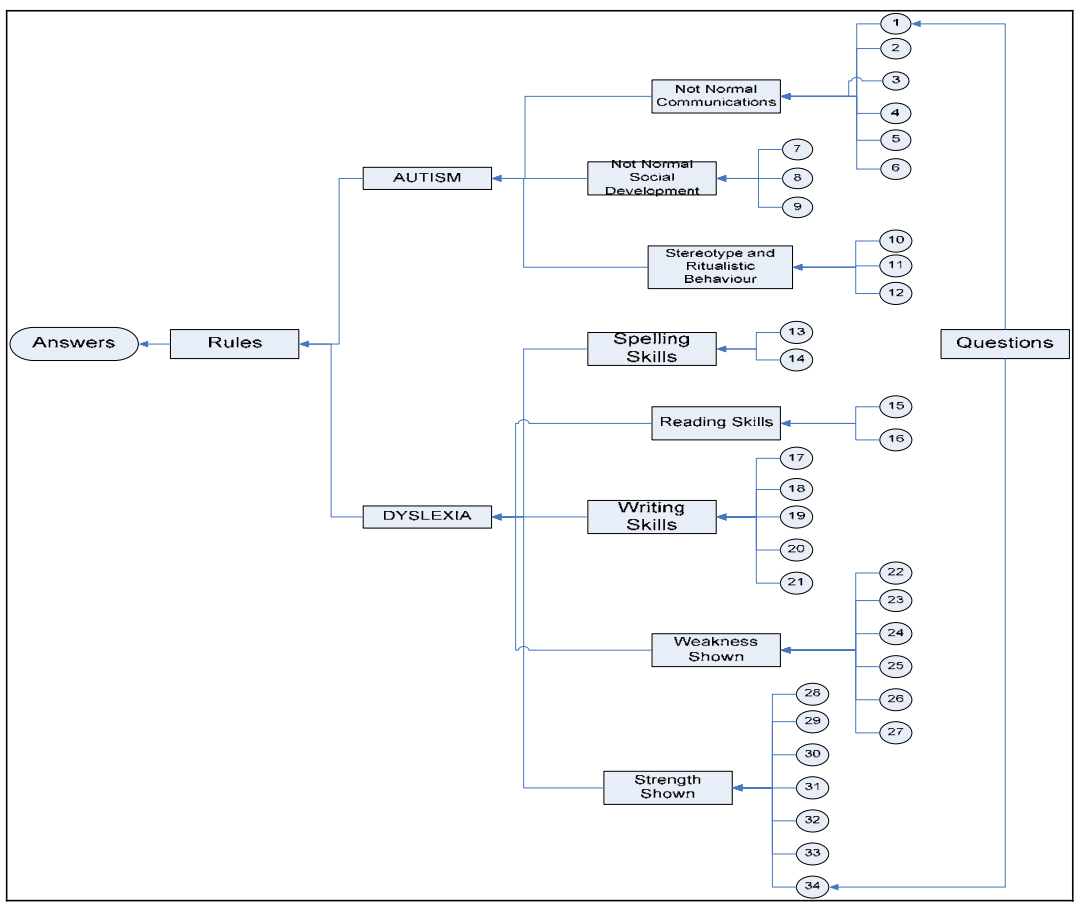

Fig. 5. Cognitive map shows the flow of overall system, from the questions to the result 
Test of Unit and the Functionality. Modules of information are tested on its ability to display the interface to user while using the system. Page that display information are static.

\section{Conclusion}

This system helps new teachers to recognize and categorize two groups of learning problems. This system also gives extra information to user through information module of Autism and Dyslexia. With this, the objective to develop this system finally achieved by helping new teachers in Special Education in categorizing type of disability among Special Education that state under the responsibility of Ministry of Education, Malaysia.

Further development of the system include, enhance more categories for type of disabilities for Special Education such as Down Syndrome, Minimal Mental Disorder and Attention Deficit Hyperactive Disorder (ADHD). Besides, additional information module like methodology of treatment and suitable education are to be added in this expert system as for the user's reference. Meanwhile, the design of this system interface can also be improved to make it more attractive, for example; the integration of animation and audio to add commercial value to this system.

\section{References}

1. Jabatan Pendidikan Khas, http: / /apps2 . emoe.gov.my/jpkhas/htm/web/profil_program.php

2. Darlington, K.: The Essence of Expert System. Prentice Hall, England (2000)

3. Le Couteur, A., Rutter, M., Lord, C., Rios, P., Robertson, S., Holdgrafer, M., McLennan, J.: Autism Diagnostic Interview: A standardized investigator-based instrument. Journal of Autism and Developmental Disorders 19, 363-387 (1989)

4. Rutter, M.: Autism Research: Lessons from the Past and Prospects for the Future. Journal of Autism and Developmental Disorders 35(2) (April 2005)

5. Lord, C., Rutter, M., Goode, S., Heemsbergen, J., Jordan, H., Mawhood, L., Schopler, E.: Autism Diagnostic Observation Schedule: A standardardized observation of communicative and social behaviour. Journal of Autism and Developmental Disorders 19, 185-212 (1989)

6. Fawcett, J., Singleton, C.H., Peer, L.: Advances in early years screening for dyslexia in the United Kingdom. Annals of Dyslexia 48(1) (December 1998)

7. Filipek, P.A., Accardo, P.J., Baranek, G.T., Cook, E.H., Dawson, G., Gordon, B., Gravel, J.S., Johnson, C.P., Kallen, R.J., Levy, S.E., Minshew, N.J., Prizant, B.M., Rapin, I., Rogers, S.J., Stone, W.L., Teplin, S., Tuchman, R.F., Volkmar, F.R.: The Screening and Diagnosis of Autistic Spectrum Disorders. Journal of Autism and Developmental Disorders 29(2) (December 1999)

8. Tsermentseli, S., O'Brien, J.M., Spencer, J.V.: Comparison of Form and Motion Coherence Processing in Autistic Spectrum Disorders and Dyslexia. Journal of Autism and Developmental Disorders 38(7) (August 2008) 